\title{
Evaluating the Potential of Liquid Smoke in Protecting Cocoa Beans against Storage Pest
}

\author{
Sutrisno $^{\text {a }}$, Courage Yaw Krah ${ }^{\text {a, }}$, Idham Sakti Harahap ${ }^{\text {b }}$, Samsudin ${ }^{c}$ \\ ${ }^{a}$ Department of Mechanical and Biosystem Engineering, Institut Pertanian Bogor (IPB University), Bogor Dramaga, 16680, Indonesia \\ ${ }^{b}$ Department of Plant Protection, Institut Pertanian Bogor (IPB University), Bogor, Dramaga, Indonesia \\ ${ }^{c}$ Indonesian Industrial and Beverage Crops Research Institute (IIBCRI), Ministry of Agriculture, Sukabumi, Indonesia \\ Corresponding author: *couragekrah@apps.ipb.ac.id
}

\begin{abstract}
Insect attack of produce in storage is a major challenge in postharvest handling and contributes to food waste and loss. Attempts to use synthetic chemicals to control this have generated other health and environmental problems. This study aimed to investigate the potential of pyrolyzed cocoa pod husk as a biopesticide (liquid Smoke (LS)) to protect cocoa beans against storage pests. The study was set up in a Completely Randomized Design (CRD) with five treatments $(10 \% ; 20 \% ; 50 \% ; 100 \%$ concentrations of LS and $0 \%$ as control). These were applied to the outer surface of mini jute sacks containing cocoa beans. A GCMS analysis of the LS detected 20 compounds. A repellence test of LS showed a very strong repellence effect, repelling almost $90 \%$ of the insect population. The feeding deterrence index also caused a reduction in bean damage from $22 \%$ in control to $7.65 \%$ for $100 \%$ LS-treated beans. Weight loss was reduced from $2.13 \%$ in control to $0.11 \%$ in the sample treated with $100 \%$ LS. The LS treatment did not cause any significant change in the FFA and pH content of the beans. The organoleptic test also proved that LS treatment did not cause any substantial change in the flavor and overall taste and aroma acceptability. Therefore, the liquid smoke can be used for protecting cocoa beans by spraying on the outer part of jute sacks containing beans.
\end{abstract}

Keywords - Cocoa beans; pyrolysis; liquid smoke; postharvest; storage pest; Corcyra cephalonica.

Manuscript received 2 Apr. 2021; revised 30 Jun. 2021; accepted 6 Aug. 2021. Date of publication 31 Dec. 2021. IJASEIT is licensed under a Creative Commons Attribution-Share Alike 4.0 International License.

\section{INTRODUCTION}

Cocoa (Theobroma cacao L.) is purported to have originated from the Amazon basin. It was grown by the indigenous peoples throughout Mexico and Central America around the pre-European colonial era. Currently, the crop is widely grown in tropical regions globally, especially in West and Central Africa, Southeast Asia, and part of Southern America regions. The name cocoa bean technically represents the seeds extracted from the matured pod/ fruit of the Theobroma cacao L. tree, which serves as the basic raw material used to manufacture high-value products [1]. The three main varieties grown worldwide are the Criollo, Forastero, and Trinitario varieties.

Ivory Coast is the largest cocoa beans producer, contributing almost 1.6 million tonnes annually [2]. Ghana comes second with an average annual production of around 800 thousand tonnes. Indonesia occupied the third position with a yearly average of 300 thousand tonnes. In Ghana, the crop employs over 800,000 smallholder families and contributes about $8.2 \%$ to GDP, while in Indonesia, more than 1,400,000 smallholder families make their living from the production of cocoa beans. It also contributes some US\$1.2 billion annually to the Indonesian economy [3].

Research on the health benefits of cocoa has proven that it possesses antioxidant properties and reduces the risk of cardiovascular attack and stroke [4]. The health-promoting properties of cocoa beans have been majorly attributed to their polyphenol content. The polyphenols compounds found in cocoa include phenolic acids, simple phenols, flavonoids, and benzoquinones. These Polyphenols in the beans account for about 12 to $18 \%$ dry weight of a whole dry bean. In another report by Gvozdjakova et al. [4], cocoa can suppress inflammation, depression, and oxidative stress in the consumer. The final quality of cocoa beans and the derivative products can be traced to three main factors: genetic, geographical, and postharvest handling [1], [5]. The former two are essential to some extent, but the latter also needs to be carried out with extra caution because it influences the marketability of the beans and can alter the attributes 
contributed by genetic and geographical factors [6]. The main activities at the postharvest stage include pod breaking, fermenting, drying, and storage/transportation. Although the methods employed in carrying them out may differ, they often give specific results common to all regardless of the method used.

Pod breaking is carried out to separate wet beans from the placenta and pod [7]. Fermentation is done to allow enzymes and microorganisms to act on the beans' carbohydrate, protein, and polyphenolic content. This later activates the formations of precursors and many other compounds that determine the aroma and taste of the product made from the cocoa beans and its resultant products [8]. The main objective of drying is to reduce the moisture content to recommended rates of $6.5-7.5 \%$; this creates unfavorable conditions for the growth of microorganisms and insects [7].

After drying, the beans are kept in storage spaces with a recommended relative humidity of $65-70 \%$ to await further processing or transportation to another destination [9].

One of the greatest challenges that often arise in storage is insect attack. It is a widespread problem that cuts across all the regions where cocoa is produced and traded [10]. The majority of the insect pests that attack beans in storage come from Coleoptera and Lepidoptera orders. Sampling carried out on stored beans in some warehouses in Ghana revealed the prevalence of the following insect pests; Corcyra cephalonica, Lasioderma serricorne, Araecerus fasciculatus, Carpophilus hemipterus, Carpophilus dimidiatus, Tribolium castaneum Cryptolestes ferrugineus, Rhyzopertha dominica, Cryptolestes pusillus Oryzaephilus mercator, and Ephestia cautella[10]. In an attempt to control these storage pests, many pesticides have been employed, which most often leave residues harmful to the handlers, consumers, and the environment at large [11. The ban on methyl bromide as a fumigant for protecting cocoa beans and other commodities created unusual pressure on the use of phosphine. The pressure led to indiscriminate use of phosphine and this also generated incidence of pest resistance among some insect species in specific regions [12]. The nature of the problem calls for the intensification of research into alternative pesticides that are effective, economical, safe for the handler, consumer, and the environment.

In cocoa beans' global trade, the current standards and quality requirements demand that the beans are well fermented, dried to appropriate moisture content (6.5-7.5\%), free of smoky and flat beans, free of abnormal odor and any evidence of adulteration[13]. There should also be no sight of living insects, frass, insect contaminants, and reasonably free from broken beans. The presence of foreign matter and pesticide residues are also checked against. These quality requirements, among other things, make postharvest handling a critical step in the cocoa bean supply chain [3], [13], [14].

In addition to the storage pest infestation that has become a major postharvest issue in the value chain of cocoa, mismanagement of the cocoa pod husk $(\mathrm{CPH})$ waste has also created a fresh cycle of problems that is negatively affecting the quantity and quality of beans harvested. According to reports from Jayeola et al. [15], cocoa pods improperly disposed of on the farm can serve as alternate hosts and hideouts for plant pathogens such as Phytophthora palmivora.
Meanwhile, some researchers have reported on the possibility of converting cocoa pod husk $(\mathrm{CPH})$ into value-added products that have the potential to be used as insecticides, antimicrobials, soil amendment products, etc. [16] [17].

These concerns signify the urgent need for finding systemic and lasting solutions to the postharvest problems in the cocoa bean value chain. As a result, this research was planned with the primary objective to investigate the potential of liquid smoke in protecting cocoa beans against storage pests, using the larva of Corcyra cephalonica as a model pest. This objective was achieved through the following subobjectives; GCMS analysis of the compounds present in $\mathrm{CPH}$ liquid smoke, determining the repellence effects of $\mathrm{CPH}$ liquid smoke against $C$. cephalonica, measuring the feeding deterrence index (FDI) of $\mathrm{CPH}$ liquid smoke against $C$. cephalonica, and investigating the effect of $\mathrm{CPH}$ liquid smoke treatment on the chemical and organoleptic qualities of cocoa beans.

\section{MATERials AND Method}

\section{A. Time and Place of Work}

A significant part of this research was carried out in the Indonesian Industrial and Beverage Crops Research Institute (IIBCRI)) in Sukabumi, from September 2020 to December 2020. Liquid smoke preparation and analysis (GCMS) was done at the Center for Research and Forest Products Development in Bogor, Indonesia.

\section{B. Tools and materials}

The main materials used for this research were cocoa pod husk, jute sack, dry cocoa beans, C. cephalonica insect larvae. Essential tools used include a pyrolysis reactor equipped with a condenser, oven, soxhlet extractor, desiccator, weighing scale, beaker, glass container, measuring cup, pipette, and blender.

\section{Research Design}

This study was set up in a Completely Randomized Design (CRD) with four replications. There were five treatments $(\tau)$ representing various concentrations of liquid smoke : $\tau_{1 \ldots} \tau_{5}=$ $10 \% ; 20 \% ; 50 \% ; 100 \%$ and control $(0 \%)$ concentrations of LS.

\section{Insect Rearing}

Sample adults of $C$. cephalonica were obtained from the entomology lab of SEAMEO BIOTROP, Bogor, Indonesia. Rearing was done inside transparent plastic containers covered with gauze to allow aeration was used for rearing insects. Three hundred adults (male \& female) of Corcyra cephalonica were introduced into the container filled with broken rice and oat. Rearing was done at room temperature $\left(27^{\circ} \mathrm{C} \% 75 \mathrm{RH}\right)$ for one month, after which third larval instar of the insects was obtained and used for the test [18].

\section{E. Preparation and Analysis of Liquid Smoke}

Cocoa pod husk (CPH) was collected as waste from the cocoa farm of IIBCRI. It was sundried to a moisture content of $19.3 \%$. The material was subjected to slow pyrolysis at a temperature of $400{ }^{\circ} \mathrm{C}$ inside a reactor with a heat rate of 56 ${ }^{\circ} \mathrm{C}$ per second for $5 \mathrm{hrs}$ [19]. The reactor was filled with $1505 \mathrm{~g}$ 
dry $\mathrm{CPH}$, which later produced $579 \mathrm{~g}$ of liquid smoke and $458 \mathrm{~g}$ of charcoal.

Liquid smoke produced from the pyrolysis of $\mathrm{CPH}$ was subjected to analysis using Gas Chromatography-Mass Spectrometry Pyrolysis technique (GCMS-QP2010, Shimadzu, Japan).

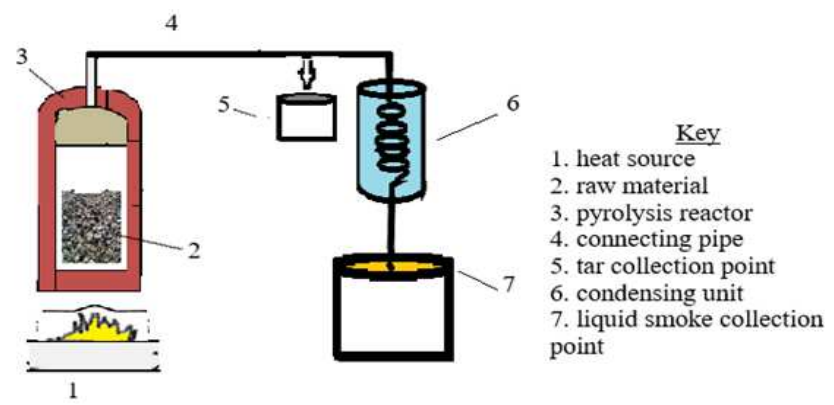

Fig. 1 Schematic of tools setup for producing LS[20]

\section{F. Repellence Test}

The Whatman No. 1 filter paper of $8 \mathrm{~cm}$ in diameter was cut into two and placed side by side in a petri dish. For every petri dish, one part of the filter paper was treated with liquid smoke of designated concentration using micro sprayers, and the other half was treated with just distilled water. The wet filter papers were room dried to evaporate liquids completely. Treated and untreated halves were attached with sellotape not to obstruct the movement of insect larvae and placed in the glass petri dish. Ten of the third instar larvae of Corcyra cephalonica were released at the filter paper center in each petri dish. Observation of the number of larvae present on both the treated and untreated halves was recorded every 30 minutes for 2 hours of experiment setting $(30,60,90$, and 120 $\mathrm{min})$. The data were expressed as percentage repellency using equation 1 .

$$
\mathrm{PR}(\%)=\frac{\mathrm{NC}-\mathrm{NT})}{\mathrm{NC}+\mathrm{NT}} \times 100
$$

$\mathrm{PR}=$ percent repellency

$\mathrm{NC}=$ number of insects at the control site

$\mathrm{NT}=$ number of insects at the treated site [21]

\section{G. Damaged Beans, Weight loss and Feeding Deterrence}

The general approach for measuring the parameters named above was done following the method used by Rajkumar et al. [22] with slight modifications. Mini jute bags of dimension $22 \mathrm{~cm} \times 14 \mathrm{~cm}$ were filled with cocoa beans $(250 \mathrm{~g})$ and 15 insect larva ( $3 \mathrm{rd}$ instar). Each bag was treated by spraying with the various concentration rates of LS in a manner that is enough to get the LS odor released into the beans without getting the sacks soaked or wet. The jute sacks were also enclosed with another sack made from soft white linen to prevent the larvae from escaping. The setup was left for two weeks in a room with an average temperature of $30^{\circ} \mathrm{C}, 68 \mathrm{RH}$, after which the mini bags of cocoa beans were opened and beans separated into two groups: damaged and undamaged. Beans in each group were counted and weighed for all sacks.

1) Damaged beans: The percentage of beans damaged was calculated using equation 2[23].

$$
\mathrm{Db}(\%)=\frac{\mathrm{Dn}}{\mathrm{Tn}} \times 100
$$

$\mathrm{Db}=$ Damaged beans

$\mathrm{Dn}=$ number of damaged beans

$\mathrm{Tn}=$ total number of damaged and undamaged beans

2) Weight loss: The weight loss percentage was calculated using the FAO Count and weigh method following equation $3[23]$.

$$
\mathrm{Wl}(\%)=\frac{(\mathrm{U} \times \mathrm{Nd})-(\mathrm{D} \times \mathrm{N} u)}{\mathrm{U}(N d+N u)} \times 100
$$

$\mathrm{W} l=$ Weight loss

$\mathrm{Nd}=$ number of damaged beans

$\mathrm{D}=$ Weight of Damaged beans

$\mathrm{Nu}=$ Number of undamaged beans

$\mathrm{U}=$ Weight of undamaged beans

Feeding Deterrence Index: The Feeding deterrence effect was calculated by using equation 4 [24].

$$
\text { FDI }(\%)=\frac{(C-T)}{C+T} \times 100
$$

$\mathrm{C}=$ weight loss of control cocoa beans

$\mathrm{T}=$ weight loss of LS treated cocoa beans

FDI $=$ Feeding Deterrence Index

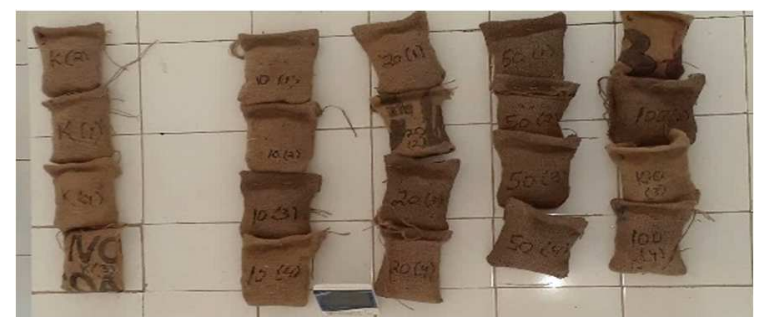

Fig. 2 Mini jute sacks of cocoa beans after treatment

\section{H. Quality Test of Cocoa Beans}

Cocoa beans were subjected to the same storage conditions as in Section $G$ but without adding insect larvae. After two weeks, moisture test, PH, FFA, and organoleptic test were carried out.

1) Moisture and PH Test: The moisture test was done using the standard oven method. PH measurement of beans was done by homogenizing powdered beans with distilled water and measuring $\mathrm{pH}$ using a pH meter (Jenway 3510 ).

2) Determination of Free Fatty Acid: The fat was extracted from powdered beans using hexane in a Soxhlet extractor (Büchi E-812/E-816 Sox). Fat obtained from the extraction was kept in the oven $\left(105^{\circ} \mathrm{C}, 30 \mathrm{mins}\right)$ then moved to the desiccator for $15 \mathrm{mins}$ to remove excess hexane. Hexane-free fat was then dissolved in warm $50 \mathrm{~mL}$ ethanol and then titrated using alkali solution $(\mathrm{NaOH} 0.1 \mathrm{~N})$. Free fatty acid content was determined by the International Office of Cocoa, Chocolate and Sugar Confection (IOCCC) method 42-1993. The Free fatty acid was calculated and expressed as the percentage using equation 5 [25].

$$
\% \mathrm{FFA}=\frac{282 \times V \times N}{10 \times \mathrm{M}}
$$

$\mathrm{FFA}=$ free fatty acid content

$282=$ Molecular mass of oleic acid

$\mathrm{V}=$ volume in $\mathrm{ml}$ of standardized $\mathrm{NaOH}$ used for titration. 
$\mathrm{C}=$ concentration of the standardized $\mathrm{NaOH}$ used for titration $\mathrm{N}=$ the normality of $\mathrm{NaOH}$ solution

$\mathrm{M}=$ the mass $(\mathrm{g})$ of cocoa bean fat

\section{Organoleptic Test}

Samples of cocoa beans were collected separately according to treatments and roasted separately at $150^{\circ} \mathrm{C}$ for 15 minutes. The roasted beans with shells removed were redistributed into small-sized ziplock bags (4x5") with unique codes and tightly sealed. A total of 40 semi-trained panelists took part. Each panelist was asked to smell and bite and cast their judgment; using a 7 points hedonic scale: 1 to 7 where 1 = 'Strongly disliked'; 2 = 'Moderately disliked'; 3 = 'Slightly disliked'; $4=$ 'Indifferent'; $5=$ 'Slightly liked'; 6 = 'Moderately liked,' and 7 = 'Strongly liked[26].

\section{RESUlTS AND DisCUSSION}

\section{A. GCMS Result of CPH Liquid Smoke Component}

GCMS analysis of the liquid smoke detected 20 compounds and their respective concentrations, as shown in Table 1 . The table shows the peaks $(\mathrm{P})$, retention time (RT), area (A), concentration (C), and names of the various compounds. The class of chemical compounds determines the aroma and flavor of liquid smokes it contains. These resultant chemical compounds are also largely affected by the kind of raw material and pyrolysis conditions such as temperature and heating rate [27], [28].

TABLE I

ORGANIC COMPOUNDS DETECTED IN LIQUID SMOKE

\begin{tabular}{|c|c|c|c|c|}
\hline $\mathbf{P}$ & RT & $\mathbf{A}$ & $\mathbf{C}$ & Name \\
\hline 1 & 9.796 & 53855958 & 2.16 & Hydrazine, 1,1-dimethyl- (CAS) N,N-Dimethylhydrazine \\
\hline 2 & 10.035 & 204742922 & 8.23 & Acetic acid (CAS) Ethylic acid \\
\hline 3 & 10.826 & 90871560 & 3.65 & 1-Propanol, 2-isopropoxy- (CAS) \\
\hline 4 & 11.668 & 672076152 & 27.01 & $\begin{array}{l}\text {-Butanamine, N-methyl-N-nitroso-(CAS) } \\
\text { Butylmethylnitrosamine }\end{array}$ \\
\hline 5 & 12.175 & 38611294 & 1.55 & 2-Butenoic acid (CAS) Crotonic acid \\
\hline 6 & 12.525 & 71129625 & 2.86 & Propanamide (CAS) Propionamide \\
\hline 7 & 12.909 & 76469570 & 3.07 & Pentanoic acid, 4-methyl- (CAS) 4-Methylvaleric acid \\
\hline 8 & 13.197 & 28890217 & 1.16 & Hexanoic acid (CAS) n-Hexanoic acid \\
\hline 9 & 13.487 & 70436406 & 2.83 & $\begin{array}{l}\text { 1-(3,4-Dihydroxy-5-Hydroxymethyl -Tetrahydro-Furan-2-Yl)- } \\
\text { lh }\end{array}$ \\
\hline 10 & 13.729 & 160473098 & 6.45 & 2H-Pyran-2-one, tetrahydro- (CAS) 5-Valerolactone \\
\hline 11 & 14.044 & 172539877 & 6.93 & 2,5-Pyrrolidinedione, 1-methyl- (CAS) N-Methylsuccinimide \\
\hline 12 & 14.343 & 139768487 & 5.62 & Cyclopropyl carbinol \\
\hline 13 & 14.557 & 180566673 & 7.25 & 2-Pyrrolidinone (CAS) Pyrrolidone \\
\hline 14 & 14.869 & 173222835 & 6.96 & Butanoic Acid, 2-Propenyl Ester (Cas) Allyl N-Butanoate \\
\hline 15 & 15.159 & 57061174 & 2.29 & 1-Decanol (CAS) Decyl alcohol \\
\hline 16 & 15.297 & 36591278 & 1.47 & 1,3-Propanediol, 2,2-Dibromo- \\
\hline 17 & 15.482 & 77959168 & 3.13 & 3-Heptanol, 2-methyl- (CAS) 2-Methyl-3-heptanol \\
\hline 18 & 15.652 & 54751197 & 2.20 & $\begin{array}{l}\text { 2(3H)-Furanone, 5-butyldihydro- (Cas) 4-Hydroxyoctanoic Acid } \\
\text {.Gamm }\end{array}$ \\
\hline 19 & 15.792 & 61520139 & 2.47 & Piperidinone (CAS) Piperidone \\
\hline 20 & 16.527 & 67489544 & 2.71 & Phenol, 2,6-dimethoxy- (CAS) 2,6-Dimethoxyphenol \\
\hline
\end{tabular}

According to Handojo et al. [29], acetic acids and other carboxylic acids are resultant products from the decomposition of the hemicellulose and cellulose component of CPH. The thermal decomposition of cellulose also yields anhydroglucose, carbonyl-containing compounds, and furans. The breakdown of hemicellulose alone is known to yield acetic acid and carbon dioxide [30], [31]. Pyrolysis of lignin produces various phenolic compounds, but the temperature of pyrolysis plays a great role in determining the kind of phenolic compound formed[19].

\section{B. Repellence effect Liquid Smoke}

Table 2 shows the percentage of insects repelled at the various concentration rates of LS. The proportion of insects repelled increased as the concentration of the LS increased. The larvae of insects can detect the repellent compounds by olfaction within a short distance compared to an adult insect.
TABLE II

DATA \pm STANDARD ERROR (SE) OF INSECTS REPELLED AT VARIOUS TIME RATES

\begin{tabular}{|c|c|c|c|c|}
\hline \multirow[b]{2}{*}{$\begin{array}{l}\text { Tmt } \\
(\%)\end{array}$} & \multicolumn{4}{|c|}{ Mean repellency (\%) } \\
\hline & 30mins & $60 \mathrm{mins}$ & 90 mins & $120 \mathrm{mins}$ \\
\hline 10 & $50.00 \pm 11.55^{\mathrm{b}}$ & $35.00 \pm 10.00^{\mathrm{b}}$ & $40.00 \pm 16.33^{b}$ & $30.00 \pm 11.55^{b}$ \\
\hline 20 & $35.00 \pm 10.00^{\mathrm{b}}$ & $\begin{array}{l}30.00 \\
20.00^{\mathrm{b}}\end{array}$ & $55.00 \pm 19.15^{\mathrm{ab}}$ & $40.00 \pm 28.28^{\mathrm{b}}$ \\
\hline 50 & $45.00 \pm 10.00^{\mathrm{b}}$ & $\begin{array}{l}40.00 \pm \\
28.28^{b}\end{array}$ & $75.00 \pm 10.00^{\mathrm{a}}$ & $55.00 \pm 10.00^{b}$ \\
\hline 100 & $90.0 \pm 11.55^{\mathrm{a}}$ & $85.00 \pm 10.00^{\mathrm{a}}$ & $85.00 \pm 19.15^{\mathrm{a}}$ & $85.00 \pm 10.00^{\mathrm{a}}$ \\
\hline StDev & 10.80 & 18.71 & 16.58 & 16.83 \\
\hline
\end{tabular}
difference in observation within the column $(P<0.05)$

The repellence effect of LS against insects is not a product of one particular compound but rather a combination of multiple compounds presents in the LS. A study done by Bonanomi et al. [32] on the repellence effect of liquid smoke 
from wood and alfafa feedstaock against Bactrocera oleaebirch revealed that $100 \%$ of the LS from both materials greatly repelled the insects. The results were similar for LS produced at both 300 and $500{ }^{\circ} \mathrm{C}$. Reppelence effect from individual chemical components like furfural, syringol, acetic acid, and methanol is short span compared to their combined effect. In another study by Urrutia et al. [24] which used LS from sunflower seed hulls against L. serricorne and T.castaneum, LS applied at $1 \mathrm{mg} \mathrm{cm}^{-2}$ was found to cause a repellence effect on both insects. They added that LS also triggered taxi responses, thus causing the insect to move further away from the LS site. Butanoic acid (Allyl NButanoate) and Hydrazine, 1,1-dimethyl from the results of the GCMS analysis in Table 1 were found to be very volatile with a strong odor that can repel insects.

\section{Percentage Bean Damage, Weightloss, Moisture Content, and FDI of treatments}

From the results in Table 3, the beans treated with 100\% LS recorded the most negligible amounts of damage, although this was not significantly different $(\mathrm{P}>0.05)$ from beans treated with other levels of LS ( $10-50 \%)$. The percentage of beans weight loss also reduced significantly ( $\mathrm{P}$ $<0.05$ ) as the level of treatment was increased from $0 \%$ to $100 \%$. The feeding deterrence effect also increased steadily as the concentration of LS treatment was increased. Treatment with $100 \%$ LS recorded the highest antifeedant effect of approximately $90 \%$. Although the moisture content of beans before treatment was $6.7 \%$, it decreased slightly (insignificantly) after two weeks of treatment. This implies the individual treatments did not contribute to any significant change in the bean's moisture content. The data also suggest that the weight loss recorded can be largely attributed to the activity of insects rather than a loss in moisture content. Another measure to make sure weight loss observed is basically due to damage from insects was the use of the count and weigh method for calculating weight loss[23].

TABLE III

DATA \pm STANDARD ERROR (SE) OF DAMAGE, WEIGHTLOSS, FDI, AND MOISTURE CONTENT OF COCOA BEANS

\begin{tabular}{lcclc}
\hline $\begin{array}{l}\text { Trmt } \\
(\%)\end{array}$ & $\begin{array}{l}\text { Damaged } \\
\text { beans (\%) }\end{array}$ & $\begin{array}{l}\text { Weight } \\
\text { loss (\%) }\end{array}$ & FDI (\%) & $\begin{array}{l}\text { Moisture } \\
\text { Content (\%) }\end{array}$ \\
\hline Cont & $21.99 \pm 3.11^{\mathrm{a}}$ & $2.13 \pm 0.25^{\mathrm{a}}$ & $0.00 \pm 0.00^{\mathrm{e}}$ & $6.44 \pm 0.41^{\mathrm{a}}$ \\
10 & $9.57 \pm 1.47^{\mathrm{b}}$ & $1.35 \pm 0.47^{\mathrm{b}}$ & $24.43 \pm 15.07^{\mathrm{d}}$ & $6.69 \pm 0.30^{\mathrm{a}}$ \\
20 & $10.50 \pm 2.60^{\mathrm{b}}$ & $0.85 \pm 0.34^{\mathrm{bc}}$ & $44.30 \pm 16.06^{\mathrm{bc}}$ & $6.59 \pm 0.23^{\mathrm{a}}$ \\
50 & $9.54 \pm 2.08^{\mathrm{b}}$ & $0.39 \pm 0.28^{\mathrm{cd}}$ & $70.15 \pm 17.81^{\mathrm{ab}}$ & $6.47 \pm 0.00^{\mathrm{a}}$ \\
100 & $7.65 \pm 1.10^{\mathrm{b}}$ & $0.11 \pm 0.02^{\mathrm{d}}$ & $90.06 \pm 2.66^{\mathrm{a}}$ & $6.56 \pm 0.25^{\mathrm{a}}$ \\
\hline StDev & 1.889 & 0.3142 & 12.72 & 0.2717 \\
\hline Different & superscript & letters within & a & column represent a significant
\end{tabular}

difference in observation within the column $(P<0.05)$

Feeding deterrence is usually targeted at the taste receptors of the insect pest. Aromatic compounds in the LS cause deterrent receptors in the insects to be stimulated to send signals to the central nervous system, blocking or interrupting the insect's perception of feeding. According to Arivoli and Tennyson [33], other antifeedant mechanisms can cause an eruption of electrical impulses that make insects unable to acquire accurate taste information to put up a suitable feeding approach. In another trial, Sapindal et al. [34] treated 3rd instar larvae of diamondback moth with LS from Azadirachta excelsa, $1 \%$ LS treatment caused about $50 \%$ reduction in the feeding of the insects. They concluded that LS from $A$. excelsa functioned as a chemoreceptor that disrupted and choked receptor cells, preventing the larva's feeding stimulus. In a review article on how volatile compounds can protect agriculture commodities in storage against insect pest attack, Singh et al. [11] mentioned that volatile compounds' repellence and antifeedant properties make the commodities look offensive, unpalatable, and unappealing. The antifeedants, in particular, induce either temporal or permanent cessation of feeding. The activities ultimately keep the item intact from damage and losses. Another outstanding benefit of using volatiles for pest control is the maintenance of ecological balance by not eliminating the natural enemies of insect pests. In a system where there is zero-tolerance for both dead and live insects in produces, volatiles substances like LS can be very useful in controlling the pest. Recent technological developments in the field have seen the blending of lignin fractions of biomass with high-density polyethylene (HDPE) to build insect repellent packaging and storage materials for food commodities [35].

\section{FFA and PH of Cocoa Beans}

The data in Table 4 shows that the cocoa bean samples' free fatty acids (FFA) remained the same regardless of LS concentration changes (treatments). The $\mathrm{pH}$ values showed some significant changes, but the changes did not follow any particular trend nor correlate with the various LS concentration treatments.

TABLE IV

DATA \pm STANDARD ERror (SE) OF PERCENTAGE FFA AND PH OF COCOA BEANS

\begin{tabular}{lll}
\hline Treatment (\%) & FFA (\%) & pH \\
\hline Control & $1.2833 \pm 0.1576^{\mathrm{a}}$ & $6.6650 \pm 0.0129^{\mathrm{a}}$ \\
10 & $1.0511 \pm 0.1455^{\mathrm{a}}$ & $6.6125 \pm 0.0050^{\mathrm{b}}$ \\
20 & $1.1741 \pm 0.1941^{\mathrm{a}}$ & $6.5800 \pm 0.0141^{\mathrm{c}}$ \\
50 & $1.2194 \pm 0.1056^{\mathrm{a}}$ & $6.5925 \pm 0.0126^{\mathrm{bc}}$ \\
100 & $1.3143 \pm 0.1781^{\mathrm{a}}$ & $6.5950 \pm 0.0058^{\mathrm{bc}}$ \\
\hline St Dev & 0.1591 & 0.0108
\end{tabular}

Different superscript letters within a column represent a significant difference in observation within the column $(P<0.05)$

According to Mounjouenpou et al.[25] FFA value of beans reflect the level of triglycerides degradation in cocoa butter. The high FFA content of a cocoa bean often results from poor postharvest handling, which triggers microbial lipase to facilitate the release of fatty acids from the triglyceride in cocoa butter.

Some of the known causes of high FFA $(>1.75)$ include beans from diseased pods, slow drying of the bean, broken beans, extended storage in damp environments, storing beans with high moisture content ( $>8 \%$ ), an infestation of insect pest and general physical integrity loss of the cocoa beans [36]. In another FFA study of cocoa beans, Oyewo and Amo [37] reported that beans damaged by insects recorded higher FFA beyond acceptable limits in contrast to intact beans, but Servent et al. [38] attributed FFA change to genotype and origin of the cocoa.

The cocoa bean used in the present study was guarded against all the above risks that could increase FFA content 
except for insect infestation. That notwithstanding, the figures recorded still fell within the acceptable limit $(<1.75)$. The possible reason for the observation could be because the storage period ( 2 weeks) was not long enough to allow damage caused by the insect to transform into FFA increase. This assertion is also backed by the control samples, which suffered significant insect damage yet recorded the same FFA as the treated samples. The fermentation process primarily influences the $\mathrm{pH}$ of cocoa beans. This occurs from the production of acetic and lactic acid. Proper drying, however, has been reported to serve as a remedy for acidic $(\mathrm{pH}<5)$ beans resulting from faulty fermentation [38].

From both FFA and $\mathrm{pH}$ data, it can be inferred that treatment with LS did not cause any significant change in both quality parameters.

\section{E. Taste and Aroma Preference Test}

The preference test on the taste and aroma of beans showed that most panelists were indifferent about the acceptability of the taste of the cocoa beans (Table 5). For aroma, panelists slightly accepted the control $(0 \%)$ and $10 \%$ concentration sample. They were indifferent about the aroma of the remaining samples' $(20 \%, 50 \%$, and $100 \%)$. The choices made by the panelist did not correlate with the concentration levels of treatment. Therefore, the sheer absence of dislike among the responses proves that LS treatment did not cause any significant deterioration in the taste and aroma properties of the beans.

According to Lemarcq et al. [39], heat treatment at $150^{\circ} \mathrm{C}$ during roasting eliminates some undesirable volatiles compounds and reduces the moisture content to about $1 \%$. It also triggers a Maillard reaction in which flavor compounds are formed, giving roasted beans a new flavor (roasty \& sweet) that is different from that of the unroasted one. LS usage as biopesticide has been primarily restricted to field crop protection and other non-food uses due to concerns over safety and the smoky smell it can produce in food. According to this study, treatment of stored cocoa beans can be an exception due to the thermal treatment process that helps evaporate the aroma residue.

TABLE V

$\mathrm{DATA} \pm \mathrm{STANDARD}$ ERROR (SE) OF TASTE AND AROMA ACCEPTABILITY OF COCOA BEANS

\begin{tabular}{lll}
\hline Treatment & Taste & Aroma \\
\hline Control & $3.83^{\mathrm{a}}$ & $5.08^{\mathrm{a}}$ \\
$10 \%$ & $3.75^{\mathrm{a}}$ & $4.88^{\mathrm{a}}$ \\
$20 \%$ & $3.70^{\mathrm{a}}$ & $4.00^{\mathrm{b}}$ \\
$50 \%$ & $3.68^{\mathrm{a}}$ & $3.83^{\mathrm{b}}$ \\
$100 \%$ & $3.60^{\mathrm{a}}$ & $4.43^{\mathrm{ab}}$ \\
\hline St Dev. & 0.569 & 0.116 \\
\hline
\end{tabular}

Different superscript letters within a column represent a significant difference in observation within the column $(P<0.05)$. Key 1. strongly dislike 2. Moderately dislike 3. Slightly dislike 4. Indifferent 5. Slightly liked 6. Moderately liked 7. Strongly liked.

\section{F. Identification of Flavour Attributes}

According to Quelal-vásconez and Pérez-esteve [36], flavor attributes in cocoa beans are formed from a combination of physical and chemical parameters. While the physical is mostly about the integrity of the beans, the chemical encompasses the volatile and nonvolatile compound constituents. The saccharides (Monosaccharides, disaccharides, oligosaccharides) contribute a sweet taste, while fatty acids result in acidic flavors.

As shown in Figure 3, the test for identifying some basic flavor attributes revealed that all samples, regardless of the LS concentration treatment, shared similar flavor attributes.



Fig. 3 Results of panelist perception of flavor attributes of various samples

Most panelists, regardless of treatments, choose roasty and musty as the detected flavors across the board. The smoky flavor was also detected by a similar number of panelists across all treatment samples, including control (without LS treatment ). This infers that the LS treatment did not induce the smoky flavor perceived by the panelist. According to Urbańska and Kowalska [40], acidity, Woody, Spicy, bitter, astringency, Sweet, fruity (Fresh Fruit), floral, nutty, and roasted flavors are the standard flavor attributes used in the flavor test.

It is important to note that the present test is not a standard test to build a cocoa flavor profile but rather to identify whether the LS treatment left any noticeable level of smoky flavor in the roasted beans. Therefore, the present results seek to point out that LS treatment of stored cocoa beans does not produce a smoky flavor in roasted beans.

\section{CONCLUSION}

GCMS analysis of the liquid smoke detected 20 compounds represented in different concentrations. Allyl Nbutanoate and Hydrazine, 1,1-dimethyl compounds, possessed a strong odor, with a high potential for insect repellent. LS at $100 \%$ concentration showed a powerful repellence effect, repelling almost $90 \%$ of the insect population. The repellence effect of 10,20 , and $50 \%$ LS similarly repelled about $50 \%$ of the larval population.

The feeding deterrence index (FDI) effect was also highest, with the $100 \%$ LS treatment repelling almost $90 \%$ of the larval population. This was, however, not significantly 
different from the performance of the LS with $50 \%$ concentration. The antifeedant effect caused a reduction in bean damage from $22 \%$ in control to $7.65 \%$ for $100 \%$ LStreated beans. Weight loss was also reduced from $2.13 \%$ in control to $0.11 \%$ in $100 \%$ LS.

Further quality checks on the beans show that LS treatment at all concentration levels did not cause any significant change in the FFA and $\mathrm{pH}$ content of the beans. The organoleptic test also proved that LS treatment caused no significant change in the flavor and overall acceptance of beans taste and aroma.

In conclusion, spraying the outer surface of jute sacks containing cocoa beans with LS can considerably protect the beans against attack by storage pests (Corcyra) and preserve quality. Liquid smoke, therefore, has the potential to be developed into an effective and sustainable biopesticide.

\section{REFERENCES}

[1] C. Abballe et al., "Cocoa beans and derived products: Effect of processing on polycyclic aromatic hydrocarbons levels," Lwt, vol. 135, no. November 2019, 2021, doi: 10.1016/j.1wt.2020.110019.

[2] ICCO, "Quarterly Bulletin of Cocoa Statistcs," Q. Bull. cocoa Stat., vol. XLIII, no. 0308-4469, pp. 20-29, 2017.

[3] J. Neilson, A. Dwiartama, N. Fold, and D. Permadi, "Resource-based industrial policy in an era of global production networks: Strategic coupling in the Indonesian cocoa sector," World Dev., vol. 135, p. 105045, 2020, doi: 10.1016/j.worlddev.2020.105045.

[4] A. Gvozdjakova et al., "Cocoa consumption and prevention of cardiometabolic diseases and other chronic diseases," Role Funct. Food Secur. Glob. Heal., pp. 317-345, 2018, doi: 10.1016/B978-012-813148-0.00019-0.

[5] L. Barbosa-Pereira, O. Rojo-Poveda, I. Ferrocino, M. Giordano, and G. Zeppa, "Assessment of volatile fingerprint by HS-SPME/GC-qMS and E-nose for the classification of cocoa bean shells using chemometrics," Food Res. Int., vol. 123, pp. 684-696, 2019, doi: 10.1016/j.foodres.2019.05.041.

[6] A. Marseglia, M. Musci, M. Rinaldi, G. Palla, and A. Caligiani, "Volatile fingerprint of unroasted and roasted cocoa beans (Theobroma cacao L.) from different geographical origins," Food Res. Int., vol. 132, p. 109101, 2020, doi: 10.1016/j.foodres.2020.109101.

[7] G. M. I. Predan, A. L. Daniela, and I. L. Iulia, "Cocoa industry-from plant cultivation to cocoa drinks production," in Caffeinated and Cocoa Based Beverages, vol. 8, 2019, pp. 489-507.

[8] L. A. Domínguez-Pérez, L. M. Beltrán-Barrientos, A. F. GonzálezCórdova, A. Hernández-Mendoza, and B. Vallejo-Cordoba, "Artisanal cocoa bean fermentation: From cocoa bean proteins to bioactive peptides with potential health benefits," J. Funct. Foods, vol. 73, no. May, p. 104134, 2020, doi: 10.1016/j.jff.2020.104134.

[9] M. S. Beg, S. Ahmad, K. Jan, and K. Bashir, "Status, supply chain and processing of cocoa - A review," Trends Food Sci. Technol., vol. 66, pp. 108-116, Aug. 2017, doi: 10.1016/j.tifs.2017.06.007.

[10] W. A. Jonfia-Essien, "Screening of new cocoa types for insect infestation and biochemical analysis of the stored beans," Pakistan J. Biol. Sci., vol. 9, no. 14, pp. 2564-2571, 2006, doi: 10.3923/pjbs.2006.2564.2571.

[11] K. D. Singh, A. J. Mobolade, R. Bharali, D. Sahoo, and Y. Rajashekar, "Main plant volatiles as stored grain pest management approach: A review," J. Agric. Food Res., vol. 4, no. January, p. 100127, 2021, doi: 10.1016/j.jafr.2021.100127.

[12] P. Agrafioti, C. G. Athanassiou, and M. K. Nayak, "Detection of phosphine resistance in major stored-product insects in Greece and evaluation of a field resistance test kit," J. Stored Prod. Res., vol. 82, pp. 40-47, 2019, doi: 10.1016/j.jspr.2019.02.004.

[13] M. S. Beg, S. Ahmad, K. Jan, and K. Bashir, "Status, supply chain and processing of cocoa - A review," Trends in Food Science and Technology. 2017, doi: 10.1016/j.tifs.2017.06.007.

[14] E. Teye, E. Anyidoho, R. Agbemafle, L. K. Sam-Amoah, and C. Elliott, "Cocoa bean and cocoa bean products quality evaluation by NIR spectroscopy and chemometrics: A review," Infrared Phys. Technol., vol. 104, p. 103127, 2020, doi: 10.1016/j.infrared.2019.103127.

[15] C. O. Jayeola, B. A. Adebowale, L. E. Yahaya, S. O. Ogunwolu, and
O. Olubamiwa, "Production of Bioactive Compounds from Waste," in Therapeutic, Probiotic, and Unconventional Foods, Elsevier, 2018, pp. $317-340$

[16] J. I. B. Janairo and D. M. Amalin, "Volatile chemical profile of cacao liquid smoke," Int. Food Res. J., vol. 25, no. 1, pp. 213-216, 2018.

[17] S. Harti, A. Indriati, and S. Dyah, "Utilization of Liquid Smoke from Cocoa pod husk (Theobroma cocoa $L$ ) for Germination of Red Seed (Capsicum annum L)," Asian J. Appl. Sci., vol. 8, no. 1, pp. 172-184, Feb. 2020, doi: 10.24203/ajas.v8i1.6045.

[18] N. Chaudhuri and S. K. Senapati, "Development and reproductive performance of rice moth Corcyra cephalonica Stainton (Lepidoptera: Pyralidae) in different rearing media," J. Saudi Soc. Agric. Sci., vol. 16, no. 4, pp. 337-343, 2017, doi: 10.1016/j.jssas.2015.11.004.

[19] J. Cheng, S. C. Hu, K. Kang, X. M. Li, Z. C. Geng, and M. Q. Zhu, "The effects of pyrolysis temperature and storage time on the compositions and properties of the pyroligneous acids generated from cotton stalk based on a polygeneration process," Ind. Crops Prod., vol. 161, no. January, p. 113226, 2021, doi: 10.1016/j.indcrop.2020.113226.

[20] C. Y. Krah, Sutrisno, Samsudin, and I. S. Harahap, "Use of liquid smoke for sustainable food preservation and postharvest loss and waste reduction (A review)," J. Appl. Phys. Sci., vol. 5, no. 2, Jun. 2019, doi: 10.20474/japs-5.2.1.

[21] Y. X. Feng, Y. Wang, Z. F. Geng, D. Zhang, B. Almaz, and S. S. Du, "Contact toxicity and repellent efficacy of Valerianaceae spp. to three stored-product insects and synergistic interactions between two major compounds camphene and bornyl acetate," Ecotoxicol. Environ. Saf., vol. 190, no. September 2019, p. 110106, 2020, doi: 10.1016/j.ecoenv.2019.110106.

[22] V. Rajkumar, C. Gunasekaran, I. K. Christy, J. Dharmaraj, P. Chinnaraj, and C. A. Paul, "Toxicity, antifeedant and biochemical efficacy of Mentha piperita L. essential oil and their major constituents against stored grain pest," Pestic. Biochem. Physiol., vol. 156, no. November 2018, pp. 138-144, 2019, doi: 10.1016/j.pestbp.2019.02.016

[23] G. Abdullahi, R. Muhamad, O. Dzolkhifli, and U. R. Sinniah, "Damage potential of Tribolium castaneum (Herbst) (Coleoptera: Tenebrionidae) on cocoa beans: Effect of initial adult population density and post infestation storage time," J. Stored Prod. Res., vol. 75, pp. 1-9, 2018, doi: 10.1016/j.jspr.2017.11.001.

[24] R. I. Urrutia, C. Yeguerman, E. Jesser, V. S. Gutierrez, M. A. Volpe, and J. O. Werdin González, "Sunflower seed hulls waste as a novel source of insecticidal product: Pyrolysis bio-oil bioactivity on insect pests of stored grains and products," J. Clean. Prod., vol. 287, no. xxxx, p. 125000, Mar. 2021, doi: 10.1016/j.jclepro.2020.125000.

[25] P. Mounjouenpou et al., "Temperature/duration couples' variation of cocoa beans roasting on the quantity and quality properties of extracted cocoa butter," Ann. Agric. Sci., vol. 63, no. 1, pp. 19-24, 2018, doi: 10.1016/j.aoas.2018.04.001.

[26] H. S. adiah Abdul Halim, J. Selamat, S. H. Mirhosseini, and N. Hussain, "Sensory preference and bloom stability of chocolate containing cocoa butter substitute from coconut oil," J. Saudi Soc. Agric. Sci., vol. 18, no. 4, pp. 443-448, 2019, doi: 10.1016/j.jssas.2018.02.005.

[27] I. Ketut Budaraga and D. P. Putra, "Study of the physical properties of liquid smoke from cocoa rind on moisture content and different pyrolysis temperature," IOP Conf. Ser. Earth Environ. Sci., vol. 542, no. 1, 2020, doi: 10.1088/1755-1315/542/1/012045.

[28] Andy, E. Abustam, R. Malaka, and S. Purwanti, "A review of Encapsulated liquid smoke," IOP Conf. Ser. Earth Environ. Sci., vol. 492, no. 1, 2020, doi: 10.1088/1755-1315/492/1/012061.

[29] L. Handojo, Cherilisa, and A. Indarto, "Cocoa bean skin waste as potential raw material for liquid smoke production," Environ. Technol. (United Kingdom), vol. 41, no. 8, pp. 1044-1053, 2020, doi: 10.1080/09593330.2018.1520306.

[30] B. Babinszki et al., "Thermal decomposition of biomass wastes derived from palm oil production," J. Anal. Appl. Pyrolysis, vol. 155, no. December 2020, 2021, doi: 10.1016/j.jaap.2021.105069.

[31] R. V. S. Silva, V. B. Pereira, K. T. Stelzer, T. A. Almeida, G. A. Romeiro, and D. A. Azevedo, "Comprehensive study of the liquid products from slow pyrolysis of crambe seeds: Bio-oil and organic compounds of the aqueous phase," Biomass and Bioenergy, vol. 123 , no. February, pp. 78-88, 2019, doi: 10.1016/j.biombioe.2019.02.014.

[32] G. Bonanomi et al., "Biochar-derived smoke-water exerts biological effects on nematodes, insects, and higher plants but not fungi," Sci. Total Environ., vol. 750, p. 142307, 2021, doi: 10.1016/j.scitotenv.2020.142307. 
[33] S. Arivoli and S. Tennyson, "Antifeedant Activity of Plant Extracts Against Spodoptera litura (Fab.) (Lepidoptera: Noctuidae)," Am. J. Agric. Environ. Sci., vol. 12, no. 6, pp. 87-96, 2013, doi: 10.5829/idosi.aejaes.2012.12.06.63178.

[34] E. Sapindal, K. H. Ong, and P. J. Hung King, "Efficacy of Azadirachta excelsa vinegar against Plutella xylostella," Int. J. Pest Manag., vol. 64, no. 1, pp. 39-44, 2018, doi: 10.1080/09670874.2017.1293866.

[35] J. Vachon et al., "Use of lignin as additive in polyethylene for food protection: Insect repelling effect of an ethyl acetate phenolic extract," Compos. Part C Open Access, vol. 2, no. July, p. 100044, 2020, doi: 10.1016/j.jcomc.2020.100044.

[36] M. A. Quelal-vásconez and É. Pérez-esteve, "Roadmap of cocoa quality and authenticity control in the industry: A review of conventional and alternative methods," no. June 2019, pp. 448-478, 2020, doi: 10.1111/1541-4337.12522.
[37] E. A. Oyewo and B. O. Amo, "Assessment of damage caused by Ephestia cautella (Walker) to stored cocoa beans," Ghana J. Agric. Sci., vol. 52, no. 1, pp. 25-31, 2018, doi: 10.4314/gjas.v52i1.

[38] A. Servent et al., "Assessment of cocoa (Theobroma cacao L.) butter content and composition throughout fermentations," Food Res. Int., vol. 107, no. February, pp. 675-682, 2018, doi: 10.1016/j.foodres.2018.02.070.

[39] V. Lemarcq et al., "Roasting-induced changes in cocoa beans with respect to the mood pyramid," Food Chem., vol. 332, p. 127467, 2020, doi: 10.1016/j.foodchem.2020.127467.

[40] B. Urbańska and J. Kowalska, "Comparison of the total polyphenol content and antioxidant activity of chocolate obtained from roasted and unroasted cocoa beans from different regions of the world," Antioxidants, vol. 8, no. 8, 2019, doi: 10.3390/antiox8080283. 